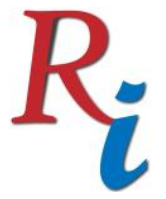

Asia Proceedings of Social Sciences

(APSS)

www.readersinsight.net/APSS

\title{
THE RELATIONSHIP BETWEEN SHARIA LIFE INSURANCE DEMAND AND ECONOMIC GROWTH IN INDONESIA
}

\section{Karin Amelia Safitri*}

Department of Insurance Administration and Actuary, Vocational higher Education Program

Universitas Indonesia

Indonesia

Karinka1803@gmail.com

*Corresponding author's Email: Karinka1803@gmail.com

Peer-review under responsibility of 5 th $^{d}$ Asia International Conference 2019 Scientific Committee http://connectingasia.org/scientific-committee/ (C) 2019 Published by Readers Insight Publisher, lat 306 Savoy Residencia, Block 3 F11/1,44000 Islamabad. Pakistan, editor@readersinsight.net

This is an open access article under the CC BY-NC-ND license (http://creativecommons.org/licenses/by-nc-nd/4.0/). 


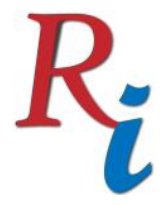

Asia Proceedings of Social Sciences

(APSS)

www.readersinsight.net/APSS

\section{A b s t r a c t}

This study aims to examine the contribution of demand for Sharia life insurance on economic growth in Indonesia. Density of insurance is an indicator used to measure the demand for Sharia life insurance. While economic growth is measured using gross domestic product. The data used is time series data for 15 years for the period 2002-2017. The analytical method used is linear regression to model the data. The findings show that Sharia life insurance contributes significantly positive on economic growth at the significance level of $5 \%$.

\section{Rese a r ch High I ight s}

Sharia life insurance is insurance that has the concept of managing or overcoming the risk of death by forming a pool of funds for the common interest following Islamic principles. Economic growth in Indonesia, which in this study was measured using indicators of gross domestic product. Gross domestic product is the production amount of goods or services that have been produced by a production unit in a country at a certain time. Demand for sharia life insurance uses insurance density proxy. Previous research that discussed the relationship between sharia life insurance and economic growth, Safitri (2019) stated that life insurance density had a statistically positive and significant effect on gross domestic product. This study examines the strength of relationship between the density of sharia life insurance and economic growth in Indonesia. This study also investigates the effect of the density of sharia life insurance on economic growth.

\section{Research Objectives}

There are 2 objectives of this study, the first, to calculate the strength of relationship between the demand of sharia life insurance and economic growth in Indonesia. Second, to see how much influence the demand of sharia life insurance has on economic growth in Indonesia.

\section{Methodology}

The country that was made the object of this research observation was Indonesia. The data used is time series data with the period 2002-2017. There are 2 observational variables for 


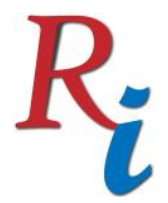

\section{Asia Proceedings of Social Sciences}

(APSS)

www.readersinsight.net/APSS

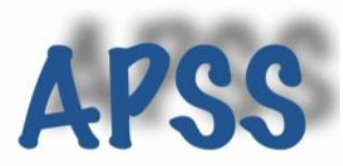

this research, the density of sharia life insurance and economic growth. The density of sharia life insurance is derived from dividing the sharia life insurance premium by the total population of the Indonesian population. While gross domestic product is used as a proxy for economic growth variables in Indonesia. The analytical method applied in this study is, first, to calculate the correlation coefficient between the two variables to see how closely the relationship between insurance density and economic growth. Second, to do linear regression modeling to see the effect of the density of Islamic life insurance on economic growth.

\section{Results}

We formulate a hypothesis to test the strength of correlation between the density of sharia life insurance and gross domestic product namely $H_{0}: \rho=0$ vs $H_{0}: \rho \neq 0$ where $\rho$ is the Pearson correlation coefficient value. We analyzed the data using Minitab 16 and then obtained the coefficient of Pearson correlation between the density of sharia life insurance and gross domestic product of 0.984 with a known $\mathrm{P}$ value of 0.00 . $\mathrm{P}$ value less than $\alpha=5 \%$, we conclude to reject $H_{0}$. Another hypothesis that we compiled to test the significant effect of the density of sharia life insurance on gross domestic product is $H_{0}: \beta_{1}=0$ vs $H_{0}: \beta_{1} \neq 0$ where $\beta_{1}$ is the regression coefficient. Based on the partial regression t test, we found that the significance value $<\alpha=5 \%$ so that $H_{0}$ was rejected. This means that the density of sharia life insurance has a significant effect on gross domestic product. Based on the regression model, it was concluded that $\beta_{1}=255646$ and $\beta_{0}=2.8$ (in billion). Positive beta value indicates the effect of insurance density on gross domestic product, which is 255646 . This finding is in line with research done by Ul Din et al. (2017) that stated the relationship between insurance density and economic growth is positive for developing countries. If insurance development is measured by insurance penetration, then Olayungbo and Akinlo (2016) found there is a positive relationship of insurance penetration to economic development in selected countries in Africa. According to Ouédraogo et al. (2016) there is a positive effect of insurance development on per capita income in 86 developing countries.

\section{Findings}

Based on Pearson's correlation coefficient it is concluded that the density of sharia life insurance contributes positively to gross domestic product having a very close positive 


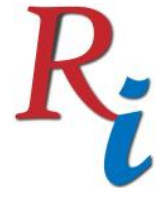

\section{Asia Proceedings of Social Sciences}

(APSS)

www.readersinsight.net/APSS

relationship. Although the density of sharia life insurance in Indonesia is growing slowly, based on the regression model it is also known that the density of sharia life insurance is able to contribute positively to gross domestic product.

\section{References}

Olayungbo, D.O., Akinlo, A.E., 2016. Insurance penetration and economic growth in Africa: Dynamic effects analysis using Bayesian TVP-VAR approach. Cogent Econ. Financ. 4. https://doi.org/10.1080/23322039.2016.1150390

Ouédraogo, I., Guérineau, S., Sawadogo, R., 2016. Life Insurance Development and Economic Growth : Evidence from Developing Countries. Études Doc. $n^{\circ} 16$ 1-33.

Safitri, K.A., 2019. Management Science Letters. Manag. Sci. Lett. 9, 957-966. https://doi.org/10.5267/j.msl.2019.4.009

Ul Din, S.M., Abu-Bakar, A., Regupathi, A., 2017. Does insurance promote economic growth: A comparative study of developed and emerging/ developing economies. Cogent Econ. Financ. 5, 1-12. https://doi.org/10.1080/23322039.2017.1390029

Author's Biography

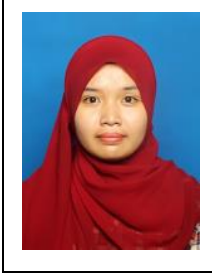

Karin Amelia Safitri, was born on 1992 in Palembang, Indonesia. She attended the mathematics education in Universitas Sriwijaya and studied applied statistics in IPB University Bogor for her second degree. Now, She is a lecturer in Vocational Higher Education Program, Universitas Indonesia, Depok. 